\title{
Renascence lace and irish lace: production contexts in artisan associations of the northeast region of Brazil
}

Márcio Monticelli Albani

Master's Degree, Universidade do Estado de Santa Catarina $\underline{\text { lattes }}$

Icléia Silveira

$\mathrm{PhD}$, Universidade do Estado de Santa Catarina

Orcid: 0000-0003-4493-9768/ lattes

Sandra Regina Rech

PhD, Universidade do Estado de Santa Catarina

Orcid: 0000-0002-0062-6914/ lattes

\section{Lucas da Rosa}

PhD, Universidade do Estado de Santa Catarina Orcid: 0000-0002-8429-2754/ lattes 


\title{
Renascence lace and irish lace: production contexts in artisan associations of the northeast region of Brazil
}

\begin{abstract}
The present study aims to identify the context of production of Renaissance and Irish lace in the artisan associations of São João do Tigre, Paraíba and Divina Pastora, in Sergipe. The qualitative and descriptive research was used and the data collection was done using bibliographical and field research, with the application of a semi-structured questionnaire. The research sample is made up of four entities, two associations and one cooperative that produce Renaissance Income in the city of São João do Tigre, in the State of Paraíba, and an association that produces Irish Income in the city of Divina Pastora, in the State of Sergipe. Through the study, it was noticed that each entity has a form of organization and that its main challenges refer to the preservation of the techniques and the commercialization of the products.
\end{abstract}

Keywords: Renaissance lace. Irish lace. Crafts. Association. 


\title{
Renda renascença e renda irlandesa: contextos de produção nas associações de artesãos da região Nordeste do Brasil
}

\begin{abstract}
RESUMO
O presente estudo objetiva identificar os contextos de produção das rendas Renascença e Irlandesa nas associações de artesãos de São João do Tigre, na Paraíba e de Divina Pastora, no Sergipe. Foi utilizada a pesquisa qualitativa e descritiva e quanto à coleta de dados utilizou-se a pesquisa bibliográfica e de campo, com aplicação de questionário semiestruturado. A amostra da pesquisa é constituída de quatro entidades, sendo duas associações e uma cooperativa que produzem Renda Renascença na cidade de São João do Tigre, no Estado da Paraíba e uma associação que produz Renda Irlandesa na cidade de Divina Pastora, no Estado de Sergipe. Por meio do estudo percebeu-se que cada entidade tem uma forma de organização e que seus principais desafios se referem à preservação das técnicas e à comercialização dos produtos.
\end{abstract}

Palavras-chave: Renda renascença. Renda irlandesa. Artesanato. Associação. 


\title{
Encaje renacentista y encaje irlandés: contextos de producción en asociaciones de artesanos del noreste de Brasil
}

\begin{abstract}
O
El presente estudio tiene como objetivo identificar los contextos de producción de encaje Renascença y Irlandés en las asociaciones de artesanos de São João do Tigre, en Paraíba y de Divina Pastora, en Sergipe. Se utilizó investigación cualitativa y descriptiva y en cuanto a recolección de datos, se utilizó investigación bibliográfica y de campo, con la aplicación de un cuestionario semiestructurado. La muestra de investigación consta de cuatro entidades, dos asociaciones y una cooperativa que producen encaje Renascença en la ciudad de São João do Tigre, en el Estado de Paraíba y una asociación que produce encaje Irlanés en la ciudad de Divina Pastora, en el Estado de Sergipe. A través del estudio se pudo constatar que cada entidad tiene una forma de organización y que sus principales desafíos están relacionados con la preservación de técnicas y la comercialización de productos.
\end{abstract}

Palabras clave: Encajes rerenacentista. Encaje irlandés. Artesanías. Asociasión. 


\section{INTRODUCTION}

Craft activities are embedded in a social and cultural context and are often located in small towns or isolated villages, where traditions are still preserved. Among the manifestations of handicrafts in the northeastern region of Brazil, can be mentioned the production of various types of manual lace, such as the Renaissance and the Irish. These artifacts are characterized as needle laces by being constructed from stitches sewn onto a paper base that is withdrawn after labor is done.

Each lace typology has been developed in a certain place and later spread throughout the region. Renascence Lace has its largest representation in the region of Cariri Paraibano, in the cities of São João do Tigre, Camalaú and Monteiro and part of Pernambuco in the cities of Pesqueira and Poções. Already the Irish Lace was developed in the city of Divina Pastora, in the region of the Continguiba Valley, in the state of Sergipe.

Since the 1970s, laces have established themselves as crafts and objects of governmental actions, being present at fairs and events. In the 1990s, Sebrae (Micro and Small Business Support Service) had a strong presence among the lacemakers, seeking to associate the use of fabric with lace in an attempt to cheapen and diversify production (FIGUEIREDO and ZACCHI, 2013).

From 2000 onwards, Programa Artesanato Solidário do Conselho da Comunidade Solidária sought to revitalize the socalled traditional crafts, as an alternative income for the community and with this, supported the creation of several entities to strengthen this type of handicraft (FIGUEIREDO, ZACCHI, 2013). 
Since then, several actions have been implemented to preserve the originality of these manifestations and to seek ways to disseminate and commercialize the products.

In view of this reality, the present study aims to identify the contexts of production of Renaissance and Irish lace in the artisan associations of São João do Tigre, Paraíba and Divina Pastora, in Sergipe. Through the research, it is possible to know the work developed by these institutions, the importance they exert in the preservation of handicrafts and the challenges they face in terms of organization and marketing of products.

The research justifies the importance of knowing and spreading the contexts of production of these artisan artifacts and strengthening the entities that work for their preservation. Through the knowledge of the reality of the associations and cooperatives visited by this author, it was possible to draw a profile of these entities, which contributes to the reflection about their role and influence in the society of which they are part, as well as new alternatives that can be devised from challenges identified. When comparing the context of each institution it will be possible to establish categories of analysis that allow evaluating how each association or cooperative solves structural, administrative and financial issues. The present study also has its importance related to the dialogue established between concrete realities very far from the great centers with theories about the craftsmanship, cultural diversity, and the Brazilian identity. In addition, from the market point of view, the study provides for the disclosure of entities as ways of marketing incomes, making them reach new clients and partners.

Regarding the classification of the research, with respect to the methodological procedures used, from the point of view of the purpose, the research is Basic, because it seeks to 
generate new knowledge for the advancement of science, but without practical application. Regarding the problem approach, it is characterized as qualitative research, since the process and mode of organization of lace associations are the focus of the study. From the point of view of the objectives, it is considered descriptive research, because, through the records of semi-structured interviews in the entities, the aim is to describe the characteristics and the context of production of the incomes. As for technical procedures, it is classified as bibliographical research, using references from books, articles, and journals already published. It can also be considered participant research, since it develops from the interaction between researcher and members of the investigated situations, in the case the interviewed lacemakers. As for the place of realization, it is identified as field research, since it proceeds from the observation of facts and phenomena of reality, such as visits to associations and cooperatives.

In order to reach the proposed objective, the theoretical foundation deals with: the concepts of handicrafts, as well as their social and cultural insertion, the specificities of the Renaissance Income of São João do Tigre and the Irish Income of Divina Pastora.

\section{CONCEPTS OF CRAFTS AND THEIR SOCIAL AND CULTURAL INSERTION}

When thinking about the concept of craftsmanship, one perceives that there is a relation with the aspects of creation, inherent in art, but retains characteristics of fidelity to a manual technique, which has been learned and passed down through generations, thus inserting objects into a historical and cultural tradition. In this sense, the publication Base 
Conceitual do Artesanato Brasileiro brings the concept of crafts:

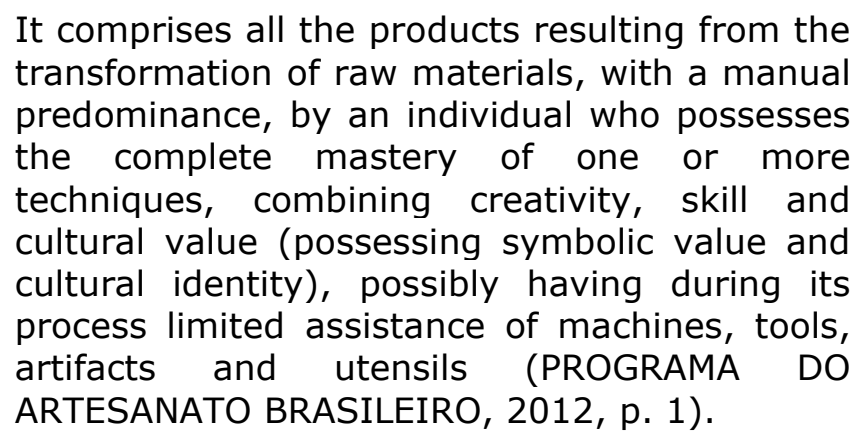

By means of the concept is meant the characteristic of manual plasticity of the craft object as predominant, and that creativity is allied to a skill of cultural value, that is, the artisan puts his personal expression through the use of a technique learned within a certain cultural nucleus.

On the difference between art and craft, Sennett (2009) states that art is constituted of more immediate knowledge, not following a technique, but often recreating the own way of doing, besides not considering a practical utility. The handicraft is a tacit knowledge, acquired with the practice and that can modify the technique by knowledge and reflection. According to the same author, being a good craftsman requires a relationship between the hand and the thought so that you can solve problems and detect them, and so explore new possibilities. In addition, handicraft has the characteristics of utility, functionality and mass production on a small scale, printing on the pieces the vision of local culture, while art creates unique aesthetic objects, inspired by the artist's worldview, without concern for practical utility or taste of the viewer.

The craftsman is a fundamental element for achieving the objectives of the craft production, it is important that he is inserted in the cultural context of the creation of the objects 
because through the hand of the craftsman, marks of time and social identity are printed in each piece. According to Base Conceitual do Artesanato Brasileiro the artisan:

Is the worker who individually exercises a manual craft, transforming raw or manufactured raw material into a finished product. It has the technical mastery of materials, tools, and processes of artisan production in its specialty, creating or producing works that have a cultural dimension, using a predominantly manual technique, and can rely on the aid of equipment, as long as they are not automatic or duplicates of parts (BASE CONCEITUAL DO ARTESANATO BRASILEIRO, 2012, p.11).

From the concept explained above, is understood that the artisan is not related to a serialized production, each object, besides a cultural identity, becomes unique, because the characteristic of the craftsmanship does not allow a perfection of a copy. In the case of lacemakers, even though they apply the same points and follow the same design, each piece becomes unique, since the climate, the raw material and even the physical and emotional state of the artisan influence the result of the product. The freedom of the craftsman is in the autonomy of the exercise of his activity, not needing big structures, equipment, energy and other factors that characterize the industry.

The Termo de Referência Atuação do Sebrae no Artesanato (2010) presents the categories of handicraft products, which are defined according to their production process, origin, use, and destination. The products are classified as folk art, craftwork, handicrafts, typical food products, semi-industrial and industrial products, industrianato, indigenous crafts, traditional crafts, cultural reference crafts, and cultural handicrafts. According to this study, the manual laces, object of this research, are inserted in the context of traditional crafts, since it is conceptualized as: 
Set of artifacts more expressive of the culture of a certain group, representative of their traditions, but incorporated into their daily life. Its production is usually of family origin or of small neighboring groups, which enables and favors the transfer of knowledge about original techniques, processes, and designs. Its importance and its cultural value are derived from the fact that it is a depository of a past, of accompanying stories transmitted from generation to generation, of being an integral and inseparable part of the customs and customs of a certain group (MASCÊNE, TEDESCHI, 2010, p. 14).

In relation to traditional crafts, the same document still states that it should have as its main strategy the identification, preservation, and promotion of products, highlighting its roots and history. To add value, it must have a system of stamps of provenance, labels of cultural contextualization, unique packaging and well-defined points of sale.

The products considered to be handmade, besides the utilitarian and aesthetic functions, it carries a strong meaning related to the culture from which it comes, since the ways of doing, the materials and the social relations inserted in this context have settled historically, and with that the product tells a lot more than its appearance.

According to Paz (1991), craftsmanship mediates, because its forms are not governed by function, but by aesthetic pleasure, which has no fixed rules. The preference for decoration is a transgression of utilitarianism. Already the proliferation of the ornamentation in the craft reveals a relation between the utility and the aesthetic contemplation. In crafts there is a swing between utility and beauty; this shuttle is connected with pleasure. The objects end up giving pleasure because they are useful and beautiful.

Related to the historical question of craftsmanship can be said that it is nourished by another time relation, which does 
not follow trends and fad, but always suffers some interference from social and cultural transformations.

An important characteristic of craft objects is the importance of the craftsman's hand, for even following a technique, each piece is unique and holds the impressions of who produced it, the feelings, aspirations and the history of its creator.

Borges (2011) uses the words of the designer Ronaldo Fraga to talk about the value of the craft product: "Behind every stitch, there is a story, there are people, there is a wonderful place, a sky of stars". The words of Ronaldo Fraga translate the identity of the craft product and the marks left by the craftsman in his pieces.

Through the craft object, the communication between the producer and the consumer is given, by the very intimate impressions that the artisan transfers to the object the consumer has access not only to a particular identity but to the characteristics of the community in which the object comes from, crafts is one of the most important forms of representation of a person's identity. Through it, not only materials and techniques but also collective values are represented.

The perfectibility of an artisanal object is only achieved through an ideal derived from a conception of life supported in its own service serving the community, so the craft needs to be more than a source of income but to be understood as a crucial element of the society's identity.

The artisan interprets techniques and his product is objective, never without function, it participates in the life of the artisan and the collective existence. He has knowledge of the culture in which he is inserted and has mastery of the materials that the area offers, transforming them into his raw material and showing in his work the environment where his 
culture is developed. The artisan also interprets inherited traditions and adds his own creativity to the objects produced, he adapts to new realities and while maintaining techniques and innovates patterns, mainly in materials and new aesthetic and functional solutions.

According to Canclini (2003): Craft supplies a gap left by industrial production that is the gap of identification and symbolic individualization of objects, it retains a more complex relation for its origin and destiny, for being an economic and aesthetic product, being non-capitalist for its manual making, but inserting itself into capitalism as a commodity.

The commercialization of handicrafts is also related to the valorization of culture as an element of affirmation of the identity of places and nations, this discourse has the objective of increasing economic practices, since culture and identity translate into products commercialized with high value, and according to Canclini (2003), the handicraft is necessary to capitalism, because it draws attention of the consumer with other aggregated values, the symbolic and cultural value, in addition, performs functions in social reproduction and division of labor, acting in other ways within the system.

[...] handicrafts can contribute to the revitalization of consumption by introducing in the industrial and urban production, at a very low cost, original designs and the symbolic differential and by referring to simpler ways of life, evoking a nature native and indigenous nostalgic that does not belong to the urban and cosmopolitan scenario (CANCLINI, 2003, p. 65).

There is, therefore, a counterpoint between industrial and artisanal production, emphasizing that the valorization given today to the artisan object comes from the confrontation provoked by the industrial production that evolved from the artisanal one historically. It is in the aspect of humanization 
that artisanal production contributes to balance the excessive rationalization of modern structures, where industrialization and its alienations are inscribed.

Borges (2011) establishes the relationship between crafts and sustainability, emphasizing that artisanal activity is historically linked to the use of local materials and to recycling, due to the proximity of raw material collection and its processing that end up having a low expenditure with transportation and inputs of the merchandise. That is why artisanal production is in tune with the notion of sustainability, comprising the concepts of environmentally responsible, economically inclusive and socially fair, encompassing the fourth pillar of sustainable development, which is cultural diversity.

Thinking about handicrafts from the point of view of sustainable development:

Craftsmanship is useful, practical and concrete. It has a visceral connection to the materials and the way they are shaped for display or use. Also essential to craftsmanship is experience: many hours working and reworking the same technique. Craft is a slow activity, with skills that mature over time, as the craftsman thinks, deeply reflects, and tests the limits of his activity (FLETCHER, 2011, p.147).

The author previously mentioned brings important concepts to conclude the relations between the artisanal production in the area of fashion and sustainable development as the binarisms on the preference of quality in relation to quantity, since as already mentioned, the craftsmanship has limits of production coming from the capacity of the human hand and the renewal of the raw material. The technique is no longer a mechanical activity, people can have a sense of fullness and reflect on what they are doing. That's why craftsmanship brings together hands and mind. It is also 
considered an active preparation as opposed to passive consumption, since consumers usually present greater criticality in relation to consumption, looking for products that fit in a social and cultural context. Crafts also develop autonomy in the face of domestication, since the artisan holds the whole process of production planning and manages to work according to his organization. Finally, the artisan production promotes a closer contact with the consumer with the social context, with the raw material and with the techniques of confection.

Manual lace is one of the greatest representations of Brazilian craftsmanship and its production is closely related to the concepts of handicraft as a cultural identity of a place, expression of the aesthetic vision and world of artisans, is placed as an alternative to the industrial market and can be understood as a sustainable production by the time of creation and use of non-polluting raw material.

\section{A RENAISSANCE HOME IN SÃO JOÃO DO TIGRE}

São João do Tigre is a municipality in the region of Cariri Paraibano, a semi-arid climate with the lowest rainfall rate in the country. The municipality is located on the border with the State of Pernambuco, with 4.578 inhabitants, according to data from the IBGE (Instituto Brasileiro de Geografia e Estatísticas) in 2007, one of the most important sources of income in this region is the production of Renaissance Lace.

According to Silva (2013), Renaissance lace receives several denominations, depending on the locality where it is produced. In Brazil, it is still known as English lace, but the predominant denomination is Renaissance lace.

Within the classification of laces can be defined: 
The renaissance is a type of needle lace, which maintains the same formal principle of the other laces of its class, which are basically constituted by concentric designs, from which sinuous and divergent lines are projected (Nóbrega, 2005, p. 37).

It is conceptualized as a needle yield by being constructed from line embroidery made on a paper basis using a single needle stitching.

Silva (2013) explains that Renaissance Lace is made with a needle to construct the plots using a kind of tape, known in Brazil by lacê, used to demarcate the spaces to be filled, forming the skeleton of the piece with varied designs, and for the production of Irish lace, produced in the city of Divina Pastora, is used a different type of lacê, made of satin and with a rounded shape. In order to make the Renaissance lace, the lacemaker has a model previously drawn on paper, and must be glued to another more resistant paper, where the ribbon will be stitched around the drawing and then placed around the cushion, and fill the void spaces with the various points that construct the fabric, as can be seen in Figure 1.

Figure 1. Making the Renaissance Lace 


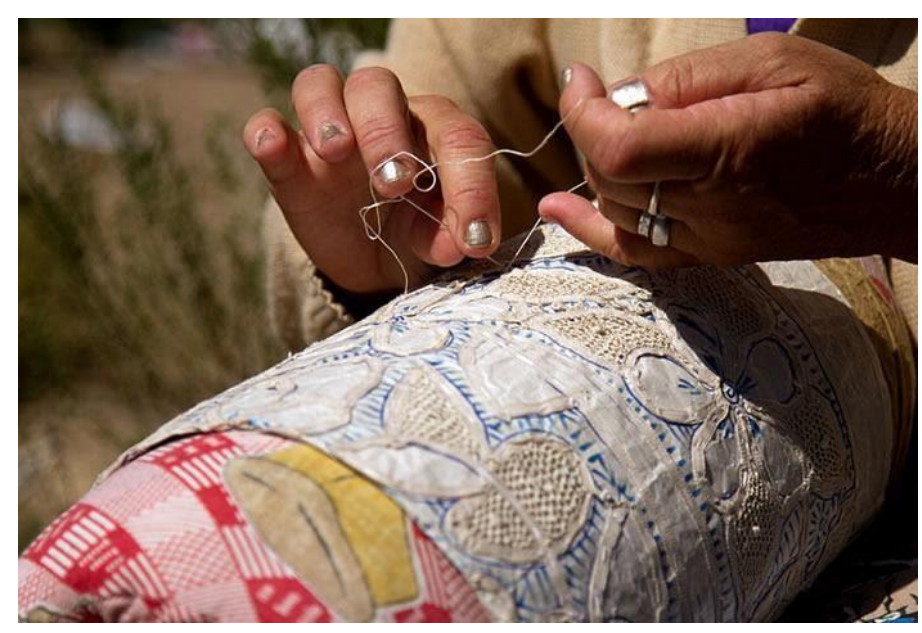

Source: <http://especiais.jconline.ne10.uol.com.br/tramas-da-renda/mulheres-rendeiras.php>. Accessed on nov. 21. 2018

The materials used to make the Renaissance Lace are the needle, cotton thread, thimble, scissors, cushion, lacê, and flatiron. Nóbrega (2005) describes the making of lace in five stages: The first stage is the creation of the risk with the design of the piece, second is the basting of the lacê on paper, the third is the weaving or making the income, the fourth is the finishing, cutting the stitches and removing from the paper base and the fifth is the washing.

On the history of the emergence of lace, Nóbrega (2005) argues that the confrontations between Christians and Arabs during the Barbarian Invasions and the Crusades in the twelfth and thirteenth centuries promoted cultural exchanges and Arab artistic style could have influenced the creation of lace in Europe from the XV century, because the floral and geometric aesthetics of the lace very much resembles the Arabic arabesques.

According to Silva (2013), the Renaissance lace originated from the ancient points of Venice, and in the seventeenth century, France began to imitate these points more simply. Still, in the seventeenth century, this type of work was losing its importance and other more delicate laces gained notoriety 
in France and Belgium, and it was not until the mid-nineteenth century that the Renaissance was again made and demanded. Having become very well-known in Europe, this lace came to be exported to different places, because it was an adornment of distinction and refinement.

The publication of the Fundo Internacional do Desenvolvimento Agrícola (2017) states that the most wellknown historical version of the arrival of the Renaissance lace in Brazil is that it was brought by French nuns still in the colonization period. In the 1930s, this handicraft arrived in the rural area of Pernambuco and in the late 1950s, Cariri, in Paraíba. Nóbrega (2005) reports that the Renaissance was kept as a secret within the convents until a nun, Maria Pastora, traveled to the city of Poção in Pernambuco and ended up teaching the young Lala, who later, seeing the difficulties brought by the drought, decided to teach the job to other women, as a possibility of income generation.

\begin{abstract}
The climate and the lands of Cariri have never been good for planting, and that is precisely why they were fertile for the rooting of the renaissance. Fertile because the lace was a viable economic alternative since there were women of all ages willing to work, anxious to change the quality of life of their families (Nóbrega, 2005, p. 49).
\end{abstract}

At the time of the production of lace in the convents, it was more concerned with liturgical and religious garments, but later when it was produced by the lacemakers, household items such as towels and tray cloths became popular. While in Europe it was only produced with white thread, in Brazil the pieces are also colored and today the lace is applied in garments and accessories.

According to Sasaoka et al., (2014), industrialization brought the mechanized production of lace and the craft of manual lace was lost and the younger generations ceased to 
be interested in the knowledge of these handicrafts. However, since the 1970s, through handicrafts policies promotion, there is a movement to recover the memory and popular traditions, through courses, re-signification, and recreation of handicrafts.

According to Silva et al. (2017), especially since the first decade of the 21st century, the demand and appreciation of lace increased by Brazilian stylists such as Ronaldo Fraga and Fernanda Yamamoto, performing a work with lacemakers from the initial process of making the products until the finalization with exhibition on the catwalks, including with the artisans participation.

The biggest challenge for lacemakers is the marketing of the pieces. In the old days they made expeditions to larger cities to offer the pieces and today the fairs are the biggest business opportunities, with fixed locations, usually on weekends and big fairs scattered throughout the country. At the end of the twentieth century and the first decade of the XXI, different public policies were created to preserve traditional handicrafts and with this assistance and incentives were offered to create associations and cooperatives that could preserve the techniques and economically develop the community. The research is inserted in this context since the entities visited were benefited by such policies and organized in that period.

\section{THE IRISH LACE OF DIVINA PASTORA}

Divina Pastora, city located in Vale do Cotinguiba, $39 \mathrm{~km}$ from Aracajú, in the State of Sergipe, is the main producing region of the Irish lace. The municipality comes from a village named Ladeira, derived from one of the many corrals of cattle existing in those lands in the seventeenth century. The locality 
grew and prospered with sugarcane plantations and the installation of mills and sugar mills. Currently, Divina Pastora has a population of 4.326 inhabitants and oil exploration accounts for a significant portion of the municipality's income, not many options for income for the residents, besides the jobs in the municipal government and the making of the Irish Income.

Melo and Silva (2014) affirm that this artifact is characterized as a kind of needle lace, similar to the Renaissance, but it is distinguished by the adoption by Divina Pastora's lacemakers of a smooth, slightly flattened and silky cord known as lacê, also called of princess lace, used in the making of soaps, collars, cuffs and flowers. This arrangement gave the Irish lace a unique identity.

According to Maia (1981), the origins of this lace go back to Europe, linking with the old-world income centers that, under the renewing winds of the Industrial Revolution, found shelter in convents of Ireland, possibly deriving its name from this. Her technique and manner of doing are described in detail in nineteenth-century European books intended for the female audience, including the Encyclopedie des Ouvrages de Dames de Thérèse de Dillmont, published in several languages and circulated in Brazil. This modality of lace reached Divina Pastora probably at the beginning of the twentieth century, with the decline of sugar activity and the teaching of craft techniques by nuns from Europe. In Divina Pastora, the Irish lace gained a characteristic of its own, because the narrow ribbon used as support was replaced by a cord a little plump, giving relief and texture to the pieces. Over time, local lacemakers incorporated new stitches copied from magazines and learned in handcrafting classes.

Instituto de Patrimônio Histórico e Artístico Nacional (2014) briefly explains the execution of the technique, stating 
that the product of this craft is a needle lace that has as its support element the lacê, an industrialized cordon, which presents itself in different forms. The shiny yarn is attached to a debouching, or drawing hazard, drawn on buttered paper and superimposed on a thick, usually brown, paper attached to a cushion. The risk is a kind of feedback to be followed and presents empty spaces that are filled by the artisan with several points executed with thread. These stitches are embroidered, forming the pattern of the lace with traditional motifs, which are reproduced and recreated continuously by the lacemakers, as shown in Figure 2.

Figure 2. Irish Income Detail.

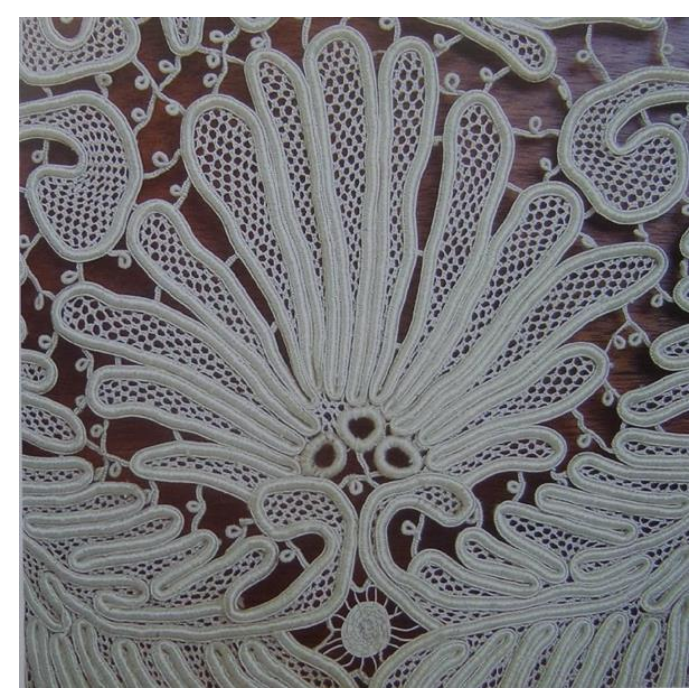

Source: IPHAN, 2014, p. 71

Regarding the types of points applied in the Irish lace, the publication of the Instituto de Patrimônio Histórico e Artístico Nacional (2014) states that there is a large repertoire of points, but the number is undefined since the lacemakers are recreating new points from magazines and courses.

In 2000, two dozen points were enumerated: pineapple, spider, basket spider, half-spider spider, part spider, round spider, spider, 
barrette, frog's mouth, butado, bee's nest, cocada, dog bone, fishbone, eyelets, last line, crow's feet, pecking or picking, netting or stitch, sianinha, tijolinho (IPHAN, 2014, 84).

It is noted that the names of the points confer a unique identity, related to elements of local nature and culture, which makes this type of handicraft receive particular characteristics and become representative of a social context. The points most used by the lace makers are shown in Figure 3.

Figure 3. Irish Income Points Sample

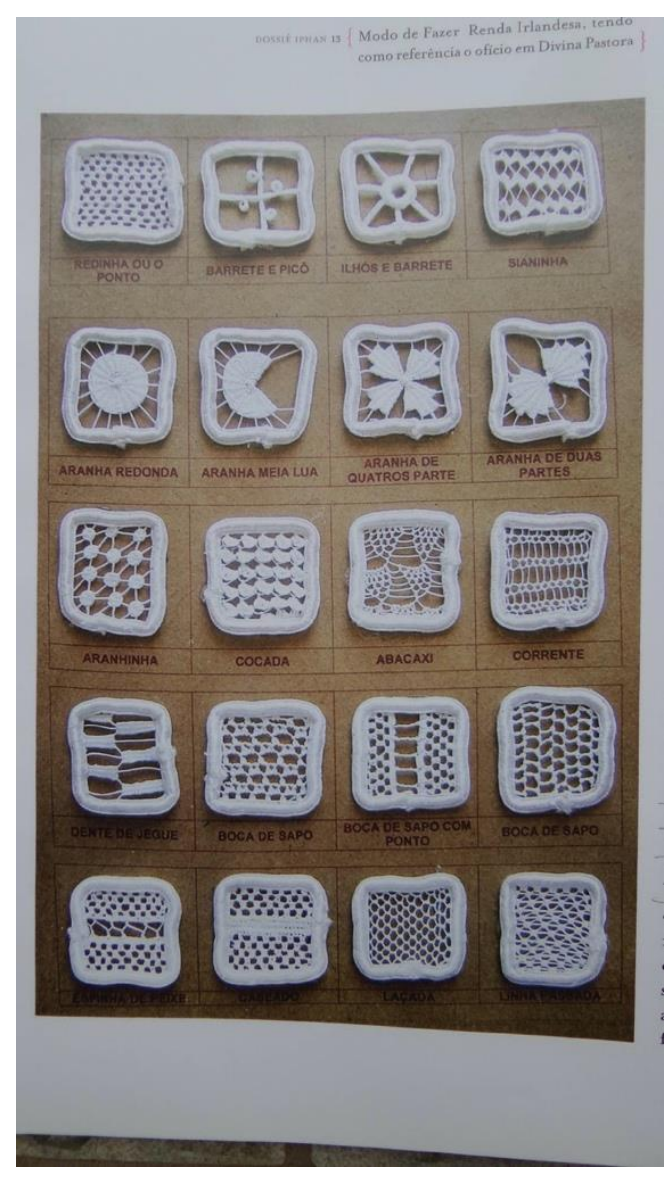

Source: IPHAN, 2014 , p. 86

Important elements in the making of the Irish lace are the debuxos, drawings made in the paper that serves as a base for the piece that will be produced. 
Elaborating the debuxo is an essential step in making lace, it is the moment of creation by the lacemaker of the piece that will be produced. Closely watched, the risks that guide the ways of the lace on paper and that define the feature and the contours of lace are proving to be the structuring element for the relationships that this way of doing organizes and adds (Figueiredo and Zacchi, 2013, p. 89).

In Figure 4, a tray cloth debuxo is shown. The layout of the drawing is where the lace will be applied and the empty spaces are filled by different points of the lace.

Figure 4. Drawing for Tray Cloth

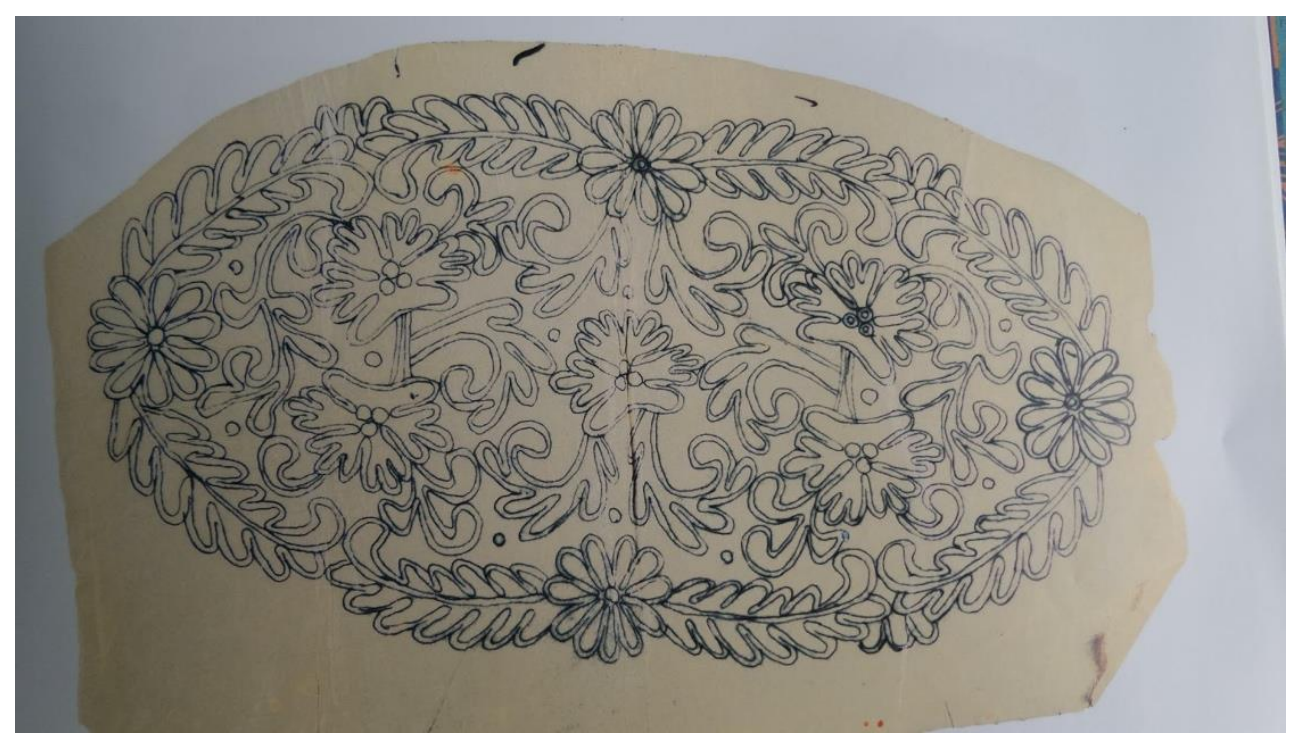

Fonte: FIGUEIREDO; ZACCHI, 2013, p. 109

The debuxos are coveted by the lace makers and they are always looking for new models. These drawings are exchanged among the artisans, sold and copied. Each new debuxo is a re-creation of forms already applied in others and recombination of elements, which impresses a sense of continuity and transformation. 
Since the 1970s, Irish lace has been established as handicraft and object of government actions, being present at fairs and events. In the 1990s, the Sebrae (Serviço de Apoio às Micro e Pequenas Empresas) had a strong presence at the Divina Pastora lacemakers, seeking to associate the use of fabric with lace in an attempt to cheapen and diversify production. During the 1990s, lacemakers had no type of formal organization, although they often worked collectively.

In the year 2000, Divina Pastora was included in the Programa Artesanato Solidário of the Conselho da Comunidade Solidária, developed by the federal government in partnership with different entities. It was a question of revitalizing the so-called traditional craftsmanship, linked to a certain local way of life, as an alternative income for the community.

ASDEREN (Associação para o Desenvolvimento da Renda Irlandesa de Divina Pastora) was created in 2000 as part of Artesanato Solidário. Through the association, new marketing channels were created and in 2006 the association, with the support of the state government, inaugurated its headquarters.

Through the supervision of Iphan in Sergipe and with the support of Prefeitura Municipal de Divina Pastora, in 2009 ASDEREN had the Irish lace inscribed in the book of knowledge and became Patrimônio Cultural do Brasil o Modo de Fazer Renda Irlandesa with reference to the trade in Divina Pastora.

In December 2012, the denomination Divina Pastora was recognized as a Identificação Geográfica (IG) for needle and lacê lace, a title granted by the Instituto Nacional de Propriedade Intelectual (INPI), which recognized the notoriety and reputation achieved by the artisans of the municipality, granting these the exclusive use of the name Divina Pastora 
to identify their products in commercial transactions. The geographical indication Divina Pastora para Renda de Agulha e Lacê was granted in the category Indicação de Procedência (IP), with Asderen as the titular.

According to interviews conducted by this author, with the lace makers in January 2018, many were the achievements of the association, but much still needs to be done in relation to the channels of commercialization and the record of making the Irish lace, because the association does not own a way of redeeming points and ways of making it.

The research carried out with the associations and cooperatives of the cities of São João do Tigre and Divina Pastora sought to explore the concepts of craftsmanship inherent in the practices of artisans, focusing on the historical and cultural tradition, trying to understand how they combine creativity with the historically learned technique. The objective was also to understand the influences of the sociocultural context on the artisanal production of these communities and which elements of everyday life are inserted in this production. The concept of sustainable craftsmanship was also compared to the existing type of production and it was also sought to verify how the concept of traditional craftsmanship applied to the context studied and how far its work is distanced from capitalist and industrial production.

\section{DATA FOUND IN RENDEZVOUS ASSOCIATIONS}

In the data collection of the research, a visit was made to four entities, two associations and a cooperative that produce 
Renaissance lace in the city of São João do Tigre, in the State of Paraíba, and an association that produces Irish lace in the city of Divina Pastora, in the State of Sergipe. In each entity, an interview was carried out with the application of a semistructured questionnaire involving questions related to the organization of associations, production and selling modes, concern with the preservation of the artisanal making and challenges and perspectives for insertion of lace into fashion products. From the interviews, comparative tables of the data found were schematized for interpretation.

The first topic addressed, the way of organization of the entity and how it was implemented, is shown in table 1.

Table 1. Form of Organization and Implementation of Entities

\begin{tabular}{|c|c|c|c|}
\hline $\begin{array}{l}\text { Association A } \\
\text { São João do Tigre }\end{array}$ & $\begin{array}{l}\text { Association B } \\
\text { São João do Tigre }\end{array}$ & $\begin{array}{l}\text { Cooperativa X } \\
\text { São João do Tigre }\end{array}$ & $\begin{array}{l}\text { Association Y } \\
\text { Divina Pastora }\end{array}$ \\
\hline $\begin{array}{l}\text { Created in } 1998 \text { to } \\
\text { attract incentives, but } \\
\text { there was already a } \\
\text { collective work. They } \\
\text { got their headquarters } \\
\text { in } 2016 \text {. Previously, they } \\
\text { only had monthly } \\
\text { meetings and organized } \\
\text { events. Today some } \\
\text { work at headquarters, } \\
\text { but most at home. The } \\
\text { association holds } \\
\text { periodic meetings, } \\
\text { offers a reading } \\
\text { workshop for children } \\
\text { and holds evaluation } \\
\text { and planning meetings } \\
\text { at the end of the year. } \\
\text { Lace makers pay a } \\
\text { monthly fee of } \$ \$ 4,00 \\
\text { and have about } 40 \\
\text { participants. Usually, a } \\
\text { lace maker weaves the } \\
\text { whole piece. }\end{array}$ & $\begin{array}{l}\text { It had its headquarters } \\
\text { inaugurated in } 2005, \\
\text { built by a project of the } \\
\text { state government of } \\
\text { Paraíba. It has about } \\
100 \text { members, but } \\
\text { around } 60 \text { are active, } \\
\text { has already reached } 150 \\
\text { in } 2017 \text {. The president } \\
\text { of the association does } \\
\text { not live in the city, but } \\
\text { when they come, they } \\
\text { hold meetings. Almost } \\
\text { all of them pick up the } \\
\text { material in the pool and } \\
\text { weave it at home. } \\
\text { Elections for president } \\
\text { of the association occur } \\
\text { every } 4 \text { years. }\end{array}$ & $\begin{array}{l}\text { Created around 2008, it } \\
\text { now has headquarters } \\
\text { with sewing machinery, } \\
\text { as they have been } \\
\text { granted government } \\
\text { incentives. Laundresses } \\
\text { work at home, but now } \\
\text { with the machinery, } \\
\text { they will go to } \\
\text { headquarters. There is a } \\
\text { presidential election of } \\
\text { the entity every two } \\
\text { years. About } 40 \text { lace } \\
\text { makers participate. }\end{array}$ & $\begin{array}{l}\text { The lacemakers had } \\
\text { already met since the } \\
1980 \text { s, but the } \\
\text { association was created } \\
\text { in the year } 2000 \text { and } \\
\text { built in several stages. } \\
\text { They had difficulties in } \\
\text { the implantation due to } \\
\text { lack of collective spirit. } \\
\text { They have had } 3 \\
\text { presidents until today, } \\
\text { the first one being } 13 \\
\text { years as president. It has } \\
\text { about } 60 \text { associates, } \\
\text { who pay a monthly fee } \\
\text { of } R \$ 5.00 \text {. }\end{array}$ \\
\hline
\end{tabular}

Source: Elaboration of Author 
It can be seen that the related entities are still recent, most of them created in the 2000s, and that their creation started from situations where lace makers already worked collectively, which facilitates their operation. As for the functioning of the headquarters, it is noticed that in most cases they are used for meetings and as a point of withdrawal, but almost all lace makers work at home. The number of participating artisans does not vary much in the entities and the majority pays a small monthly fee. Another common point is that smaller pieces are made by a single lace maker, but larger pieces are made in parts by different artisans.

The second point, outlined in table 2 , deals with the forms of production and commercialization of lace within the entities.

Table 2. Production and Marketing Modes

\begin{tabular}{|c|c|c|c|}
\hline $\begin{array}{l}\text { Association A } \\
\text { São João do Tigre }\end{array}$ & $\begin{array}{l}\text { Association B } \\
\text { São João do Tigre }\end{array}$ & $\begin{array}{l}\text { Cooperativa X } \\
\text { São João do Tigre }\end{array}$ & $\begin{array}{l}\text { Association Y } \\
\text { Divina Pastora }\end{array}$ \\
\hline $\begin{array}{l}\text { The entity pays the lace } \\
\text { maker per woven fabric } \\
\text { ball, being an average } \\
\text { of } R \$ 50.00 \text { and then } \\
\text { applies a percentage of } \\
\text { profit in the sale of the } \\
\text { pieces. Has already } \\
\text { worked with a stylist. } \\
\text { The association puts a } \\
\text { percentage of } 15 \% \text { in } \\
\text { the value of the product } \\
\text { to participate in fairs, } \\
\text { being } 5 \% \text { for the entity } \\
\text { and } 10 \% \text { for the lace } \\
\text { maker that goes to the } \\
\text { event. Lace maker who } \\
\text { weaves enough receives } \\
\text { about } R \$ 300.00 \\
\text { monthly. It has support } \\
\text { from Sebrae, which } \\
\text { forwards orders and } \\
\text { organizes events. }\end{array}$ & $\begin{array}{l}\text { Lace makers work for } \\
\text { skeins, in the average } \\
\text { price of } R \$ 45.00 \text {. When } \\
\text { there are larger pieces, } \\
\text { they divide into parts } \\
\text { among some lace } \\
\text { makers. Most of the } \\
\text { work is commissioned } \\
\text { by a stylist, who creates } \\
\text { the basic model and the } \\
\text { president of the } \\
\text { association takes the } \\
\text { risks and suggests the } \\
\text { points to be applied. On } \\
\text { average a lace maker } \\
\text { earns } R \$ 200.00 \\
\text { monthly. }\end{array}$ & $\begin{array}{l}\text { Lace maker buys the } \\
\text { material in the } \\
\text { cooperative, receive the } \\
\text { risks ready and market } \\
\text { products at home. The } \\
\text { entity organizes the } \\
\text { participation of } \\
\text { laceholders in fairs in } \\
\text { Paraíba and in other } \\
\text { states. The price should } \\
\text { be the same for equal } \\
\text { parts. They receive } \\
\text { orders from other states } \\
\text { and ordered models } \\
\text { cannot be copied. They } \\
\text { can not make a salary } \\
\text { because they sell very } \\
\text { little. }\end{array}$ & $\begin{array}{l}\text { The lace makers take } \\
\text { the line and the risk, } \\
\text { sometimes tacked, in } \\
\text { the headquarters, they } \\
\text { give the work and when } \\
\text { the piece is sold the } \\
\text { association pays the } \\
\text { lacemaker. The prices } \\
\text { are evaluated by the } \\
\text { board of the association } \\
\text { according to the } \\
\text { amount of line used and } \\
\text { the points applied. They } \\
\text { sell it in fairs of several } \\
\text { states, in the physical } \\
\text { store in the } \\
\text { headquarters of the } \\
\text { association and by } \\
\text { orders. }\end{array}$ \\
\hline
\end{tabular}




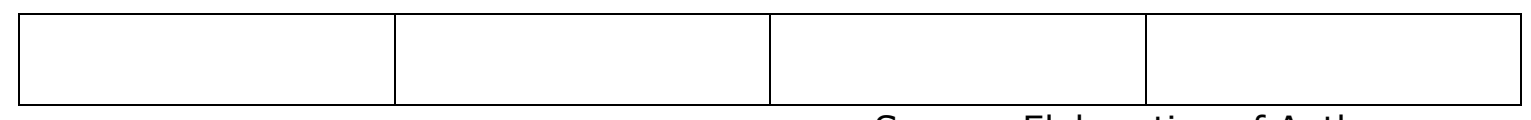

Source: Elaboration of Author

While Associations A and B work with value of ball, that is, the lace maker receives by the amount of line applied in the work, in the Cooperative $X$ the lace makers buy the material in the entity and in the Association $Y$, they buy the material and soon the entity sells the product with a profit margin and pay a value to the lace maker. The data demonstrate that the associations have created a specific way of allocating price to the product and that the values are decided by the boards of the entities. Associations A and B have already worked with designer projects and the others have their selling focused on orders and fairs. It is understood that the fairs are the main way of publicizing and selling the products and therefore it is very important for the public and private incentive to this type of event. As for the average value of financial compensation of artisans, it is noticed that it is very low and only with much production they manage to increase their income.

Another point to be analyzed in the research is the concern and the ways of preserving the technique, developed by the entities. The summary of the data is presented in Table 3.

Table 3. Concern about the Preservation of Handicrafts

\begin{tabular}{|l|l|l|l|}
\hline $\begin{array}{l}\text { Association A } \\
\text { São João do Tigre }\end{array}$ & $\begin{array}{l}\text { Association B } \\
\text { São João do Tigre }\end{array}$ & $\begin{array}{l}\text { Cooperativa X } \\
\text { São João do Tigre }\end{array}$ & $\begin{array}{l}\text { Association } \mathbf{Y} \\
\text { Divina Pastora }\end{array}$ \\
\hline $\begin{array}{l}\text { They do not have a } \\
\text { specific project for lace } \\
\text { preservation, but they } \\
\text { encourage the groups } \\
\text { not to become } \\
\text { discouraged. They make } \\
\text { the memory of trade, }\end{array}$ & $\begin{array}{l}\text { Some members } \\
\text { dominate more than } \\
100 \text { points and create } \\
\text { new points. The } \\
\text { institution has ex-officio } \\
\text { memory with the } \\
\text { registration of these }\end{array}$ & $\begin{array}{l}\text { Young girls no longer } \\
\text { want to make lace. To } \\
\text { preserve it is necessary } \\
\text { to create markets for } \\
\text { selling. There is no way } \\
\text { to register the points }\end{array}$ & $\begin{array}{l}\text { They work with } \\
\text { traditional models but } \\
\text { do not have a proper } \\
\text { form of registration. }\end{array}$ \\
$\begin{array}{l}\text { They consult books and } \\
\text { publications and learn }\end{array}$ \\
\hline
\end{tabular}




\begin{tabular}{|l|l|l|l|}
\hline $\begin{array}{l}\text { which is a showcase of } \\
\text { the points applied by } \\
\text { the association. }\end{array}$ & $\begin{array}{l}\text { points. There has } \\
\text { already been an } \\
\text { initiative of courses for } \\
\text { the younger ones. }\end{array}$ & $\begin{array}{l}\text { and techniques in the } \\
\text { entity. }\end{array}$ & $\begin{array}{l}\text { other points with the } \\
\text { master lace maker. }\end{array}$ \\
\hline
\end{tabular}

Source: Elaboration of Author

While Associations $A$ and $B$ build their own memoirs to record the points applied by lace makers, Cooperative $X$ and Association $Y$ do not have any form of lace memory preservation, they depend on the knowledge of older lace makers or masters to learn others points. It is also noticed that Association Y, which works with Irish lace, does not create new points or variances, while the other entities have the creation of new points and risks. Although they realize the need, none entity has a project to preserve crafts and teach the new generations.

The perception of the entities about their challenges and perspectives and the insertion of lace into fashion products were also analyzed in this study, as shown in Table 4.

Table 4. Challenges and Perspectives for Income Insertion in Fashion Products

\begin{tabular}{|c|c|c|c|}
\hline $\begin{array}{l}\text { Association A } \\
\text { São João do Tigre }\end{array}$ & $\begin{array}{l}\text { Association B } \\
\text { São João do Tigre }\end{array}$ & $\begin{array}{l}\text { Cooperativa X } \\
\text { São João do Tigre }\end{array}$ & $\begin{array}{l}\text { Association Y } \\
\text { Divina Pastora }\end{array}$ \\
\hline $\begin{array}{l}\text { Has the project of } \\
\text { working with fashion } \\
\text { products, but today they } \\
\text { make more pieces for } \\
\text { the home, } \\
\text { understanding that } \\
\text { clothing should be the } \\
\text { focus. The challenge is } \\
\text { to reach new audiences } \\
\text { and expand trade. }\end{array}$ & $\begin{array}{l}\text { They work more on } \\
\text { demand for designer } \\
\text { clothing, but they need } \\
\text { to expand the market. }\end{array}$ & $\begin{array}{l}\text { Before they made only } \\
\text { pieces for the house, but } \\
\text { today they make clothes } \\
\text { and applications. The } \\
\text { main challenge is to } \\
\text { create selling markets. }\end{array}$ & $\begin{array}{l}\text { Most of the pieces are } \\
\text { for the home but have } \\
\text { already had designs to } \\
\text { work with clothing. } \\
\text { Today they make some } \\
\text { accessories. The main } \\
\text { challenge is the } \\
\text { production of milk. They } \\
\text { also need a team to } \\
\text { work with digital } \\
\text { commerce and aim to } \\
\text { reach European markets. }\end{array}$ \\
\hline
\end{tabular}

Source: Elaboration of Author 
A common point for all entities is that the main challenge is to build new markets and forms of selling because, in recent years, sales have fallen a lot. It is also noticed that most of the entities work with pieces for the home, while one, Association A, already produces more pieces of clothing, due to the partnership with a stylist. The Entrepreneurial Vision of the $Y$ Association stands out by perceiving the digital environment as an important opportunity and focusing on the European market as a means of increasing the value of the product.

\section{FINAL CONSIDERATIONS}

Considering the general objective of this study, which is to identify the contexts of production of Renaissance and Irish laces in the associations of artisans of São João do Tigre, Paraíba and Divina Pastora, in Sergipe, it is possible to establish relations between the theoretical foundations exposed the handicrafts and the laces studied with the data found in the interviews and visits to the entities.

The production context of the associations and cooperative researched reveals different elements approached by the concepts of crafts: the lace making uses techniques learned in the community, following a historical and cultural tradition. During the interviews, it was possible to see that lacemakers combine creativity, skill, and cultural value, since they follow a traditional way of doing, but insert innovations such as the types of pieces, line colors, and creation of new points and motifs. As a characterization of the artisanal production, it is also observed that the artisans and their work are inserted in a cultural context that, in turn, influences this production: Communities are isolated and few are the opportunities of commercialization of the pieces, being restricted to fairs and 
sales at home; during the making of the lace the craftsmen sing traditional verses that they learned with their ancestors and many of the pieces produced have Christian motives, expression of the local religiosity.

Laces are still characterized as crafts due to their nonserialized production because although the types of pieces are the same, the designs are modified and each artisan prints his identity in the way of doing and in the variation of applied points.

The production of Renascence and Irish laces is also part of the traditional handicrafts concept brought by Mascêne and Tedeschi (2010), because their work is incorporated into the daily life of the lacemakers, it is a depository of a traditional past that accompanies cultural and religious traditions and distance of capitalist production by the rhythm of production.

The aforementioned laces are still considered as sustainable products due to their decelerated production, constituting parts with cultural reference and the use of cotton fiber lines.

Through the data found in the interviews, it was possible to perceive that culturally the entities already had ways of working collectively before the implantation of the associations, which facilitated its operation. In addition, each entity has its peculiar form of organization, especially as regards the establishment of the price of products and modes of retribution to artisans. As for the ways of preserving the technique, the most outstanding are the memoirs produced by the Renaissance lace associations, while the Irish lace does not yet have a specific form. On the challenges and perspectives of the entities, it is noticed that there is a common lack of markets and forms of commercialization, to generate income and to attract new generations to work. 
In view of the above, it is understood that public policies or private initiatives are needed to support the production of this type of handicraft, especially in relation to commercialization. Some fairs have already been promoted, but other actions are needed to reach new markets and more effectively disseminate crafts.

\section{REFERENCES}

BORGES, Adélia. Design + Artesanato - O Caminho Brasileiro. São Paulo: Terceiro Nome, 2011.

CANCLINI, Nestor Garcia. As Culturas Populares no Capitalismo. São Paulo: Brasiliense, 1983.

FIGUeIREDO, Wilmara; ZACCHI, Marina. Divina Pastora: Caminhos da Renda Irlandesa. Rio de Janeiro: IPHAN, 2013.

FUNDO INTERNACIONAL DE DESENVOLVIMENTO AGRÍCOLA. Pontos e Histórias: Renda Renascença e Mulheres Rendeiras. Instituto Interamericano de Cooperação para a Agricultura, Salvador: IICA, 2017.

INSTITUTO DO PATRIMÔNIO HISTÓRICO E ARTÍSTICO NACIONAL. Modo de Fazer Renda Irlandesa tendo como Referência o Ofício em Divina Pastora. Brasília: IPHAN, 2014.

MASCÊNE, Durcelice Cândida; TEDESCHI, Maurício. Termo de Referência: Atuação do Sistema SEBRAE no Artesanato. Brasília, 2010. Disponível em: http://intranet.df.sebrae.com.br/download/uam/Pesquisa/Artesana to/Termo\%20de\%20Referencia\%20Artesanato\%202010.pdf.

Acesso em: 10 nov.2018.

MELLO, Janaína Cardoso de; SILVA, Stefanni Patrícia Santos. Artesanato de Renda Irlandesa em Sergipe: Histórias de Vida, Histórias de Ofício. Revista História, Histórias- Revista do Programa de Pós-Graduação em História da UNB. Brasília, Vol.2, no 4, 2014.

NOBREGA, Christus. Renda Renascença: Uma Memória de Ofício Paraibana. João Pessoa: Editora do Sebrae, 2005.

OLIVEIRA, Heyse Souza de. O Ofício do saber rendar: Gênero e Práticas Locais Enraizados no Município de Divina Pastora-SE. Artigo apresentado no VIII Congresso Internacional de História. 2017. Disponível em: http://www.cih.uem.br/anais/2017/trabalhos/3400.pdf. Acesso em 7 out. 2018.

PAZ, Octavio. Ver e Usar: Arte e Artesanato. In: ConvergênciasEnsaios sobre Arte e Literatura, tradução: Moacir Werneck de Castro, Rio de Janeiro: Rocco, 1991. 
PROGRAMA DO ARTESANATO BRASILEIRO. Base Conceitual do Artesanato Brasileiro. Brasilia: Ministério do Desenvolvimento, Indústria e Comércio Exterior, 2012. Disponível em: https://manosdeartesano.files.wordpress.com/2013/06/baseconceptual-del-artesano-brasileiro.pdf. Acesso em: 10 nov. 2018.

SASAOKA, Silvia; MENEZES, Marizilda dos Santos; MOURA, Mônica. A Renda Artesanal e suas Aplicações na Moda. $1^{\circ}$ Colóquio de Moda, 2014.

Disponível em: http://www.coloquiomoda.com.br/anais/Coloquio\%20de\%20Moda $\% 20-\% 202014 / C O M U N I C A C A O-O R A L / C O-E I X O 1-D E S I G N / C O-$ EIXO-1-A-renda-artesanal-e-suas-aplicacoes-na-moda-SilviaSasaoka.pdf. Acesso em: 7 out. 2018

SENNETT, Richard. O Artífice. São Paulo: Record, 2009.

SILVA, Emanuelle Kelly Ribeiro da. Artesanato: bem cultural, bem de consumo, objeto de pesquisa. In: Quando a Cultura entra na Moda. Fortaleza: Edições UFC, 2011.

SILVA, Fabiana de Miranda; SANTOS, Geovane Silva; OLIVEIRA, Romário Lustosa. A Renda Renascença e os Enredamentos de sua Absorção no Mercado Nacional e Internacional da Moda. Artigo apresentado no II CONIDIS- Congresso Internacional da Diversidade do Semiárido. 2017. Disponível em: http://www.editorarealize.com.br/revistas/conidis/trabalhos/TRAB ALHO_EV074_MD1_SA11_ID1296_28092017125141.pdf. Acesso em: 7 out. 2018

SILVA, Gezenildo Jacinto. Rendas que se tecem, Vidas que se cruzam: Tramas e Vivências das Rendeiras de Renascença do Município de Pesqueira-PE. Dissertação de Mestrado em História da Universidade Federal de Pernambuco. 2013. Disponível em: https://repositorio.ufpe.br/handle/123456789/11359. Acesso em: 7 out. 2018. 